\title{
Biosorption of Heavy Metals from Fertilizer Industrial Waste Water Using Rice Husk (RH) and Groundnut Husk (GH) Powder in a Packed Bed Bioreactor
}

Nzelibe HC* and Ibrahim KLC

Department of Biochemistry, Ahmadu Bello University, Zaria, Kaduna State, Nigeria

\begin{abstract}
Groundnut husk $(\mathrm{GH})$ and Rice husk $(\mathrm{RH})$ were used as adsorbents to remove $\mathrm{Mn}^{2+}, \mathrm{Zn}^{2+}$ and $\mathrm{Pb}^{2+}$ ions from fertilizer industrial waste water. Continuous adsorption experiment was conducted to examine the effect of adsorbent mass, $\mathrm{pH}$, temperature and adsorbent combination on adsorption of $\mathrm{Mn}^{2+}, \mathrm{Zn}^{2+}$ and $\mathrm{Pb}^{2+}$ from fertilizer industrial waste water. The results showed that the adsorption of the metal ions was adsorbent mass, $\mathrm{pH}$, and temperature dependent. The optimum adsorbent mass was $60 \mathrm{~g}$, optimum pH was $\mathrm{pH} 5$ and $\mathrm{pH} 6$ and optimum temperature was $60^{\circ} \mathrm{C}$ for adsorption of heavy metal ions. The Langmuir biosorption isotherm provided the best fit for sorption of $\mathrm{Mn}^{2+}, \mathrm{Zn}^{2+}$ and $\mathrm{Pb}^{2+}$ using groundnut husk as indicated by their correlation coefficient $\left(\mathrm{R}^{2}\right)$ of $0.998,0.676$ and 0.297 while the freundlich biosorption isotherm had the best fit using rice husk as indicated by their correlation coefficient $\left(R^{2}\right)$ of $0.332,0.041$ and 0.556 for $\mathrm{Mn}(\mathrm{II}), \mathrm{Zn}(\mathrm{II})$ and $\mathrm{Pb}$ (II) respectively. The study also showed that groundnut husk and rice husk can be efficiently used as low cost alternative for removal of $\mathrm{Mn}^{2+}, \mathrm{Zn}^{2+}$ and $\mathrm{Pb}^{2+}$.
\end{abstract}

Keywords: Adsorption; Isotherm; Adsorbents; Langmuir; Freundlich

\section{Introduction}

Waste water from numerous industries such as paints and pigments, glass production, mining operations, metal plating, fertilizer and battery manufacturing processes are known to contain contaminants such as heavy metal [1]. Heavy metals such as $\mathrm{Pb}, \mathrm{Cd}, \mathrm{Cr}, \mathrm{Ni}, \mathrm{Zn}, \mathrm{Cu}$ and $\mathrm{Fe}$ are present in industrial waste water, these heavy metals in waste water are not biodegradable and their existence in receiving lakes and streams causes bioaccumulation in living organisms, which leads to several health problems in animals, plants and human beings such as cancer, kidney failure, metabolic acidosis, oral ulcer, renal failure. As a result of the degree of the problems caused by heavy metals pollution, removal of heavy metals from waste water is important [2]. Investigation into new and cheap methods of metal ions removal has been on the increase lately. Recently efforts have been made to use cheap and available agricultural wastes such as coconut shell, orange peel, rice husk, peanut husk and sawdust as adsorbents to remove heavy metals from waste water [1].

The removals of these hazardous materials may be performed using various techniques, including precipitation, membrane filtration, ion exchange, sorptive flotation and adsorption [2]. The removal of heavy metals via adsorption over solid adsorbents, e.g. activated carbons and others is one of the most convenient methods used.

Biosorption is a physiochemical process that occurs naturally in certain biomass which allows it to passively concentrate and bind contaminants onto its cellular structure [3]. Though using biomass in environmental cleanup has been in practice for a while, scientists and engineers are hoping this phenomenon will provide an economical alternative for removing toxic heavy metals from industrial waste water and aid in environmental remediation.

Rice hulls are the coatings of seeds, or grains of rice to protect the seed during the growing season, the hull is formed from hard materials, including opaline silica and lignin. Groundnut hull is an agricultural based waste material commonly called groundnut husk, peanut hulls, groundnut shells, peanut shells. Belongs to the specie Arachis hypogaea L. and these materials have the potential to sequester metals from solutions $[4,5]$.
This research was carried out from January 2015-April 2015 at the Department of Biochemistry, Ahmadu Bello University, Zaria, Kaduna State and its focused on investigating the potential of rice husk and groundnut husk agro waste in biosorption of heavy metals from fertilizer industrial waste water.

\section{Materials and Methods}

\section{Preparation of biosorbent}

The biosorbents used were rice husk and groundnut husk, obtained from a local farm at Samaru, Zaria, Kaduna State, Nigeria. The rice husk and groundnut husk were identified at the herbarium in the Department of Biological Science Ahmadu Bello University Zaria. The adsorbents were washed with Acetone to disinfect, and boiled with deionised water for $30 \mathrm{~min}$ dried and then pulverized.

\section{Packed bed bioreactor system}

The reactor system used in this study consists of industrial waste water as a flowing stream and a $30 \mathrm{~cm}$ long and $3 \mathrm{~cm}$ internal diameter plastic column. The column was packed with a known amount of powdered rice husk and groundnut husk separately. The process was operated in a down flow mode; the industrial wastewater was fed into the reactor and emerges as stream of product. The product was then collected at the bottom of the column and quantified.

*Corresponding author: Nzelibe HC, Department of Biochemistry, Ahmadu Bello University, Zaria, Kaduna State, Nigeria, Tel: +23407067430505; E-mail: chrisb54life@gmail.com

Received April 22, 2017; Accepted May 02, 2017; Published May 05, 2017

Citation: Nzelibe HC, Ibrahim KLC (2017) Biosorption of Heavy Metals from Fertilizer Industrial Waste Water Using Rice Husk $(\mathrm{RH})$ and Groundnut Husk (GH) Powder in a Packed Bed Bioreactor. J Environ Anal Toxicol 7: 466. doi: 10.4172/2161-0525.1000466

Copyright: @ 2017 Nzelibe HC, et al. This is an open-access article distributed under the terms of the Creative Commons Attribution License, which permits unrestricted use, distribution, and reproduction in any medium, provided the original author and source are credited. 
Citation: Nzelibe HC, Ibrahim KLC (2017) Biosorption of Heavy Metals from Fertilizer Industrial Waste Water Using Rice Husk (RH) and Groundnut Husk (GH) Powder in a Packed Bed Bioreactor. J Environ Anal Toxicol 7: 466. doi: 10.4172/2161-0525.1000466

Page 2 of 5

\section{Effects of different experimental conditions}

Since adsorption is affected by physical and chemical variables, the influence of adsorbent mass, $\mathrm{pH}$, temperature and adsorbent combination were investigated in this study.

\section{Effect of adsorbent mass}

Varying masses of adsorbents (20-70 g) were weighed separately and each mass was packed into the column of the same length, waste water was allowed to flow into the column at a flow rate of $5 \mathrm{ml} \mathrm{min}$ 1. The effluent was collected and analyzed using atomic absorption spectrophotometer (AAS).

\section{Effect of $\mathrm{pH}$}

Over a $\mathrm{pH}$ range of 3-8, the effect of $\mathrm{pH}$ on adsorption of metal ions was studied. Waste water was allowed to flow into the column packed with $40 \mathrm{~g}$ of adsorbents separately at a flow rate of $5 \mathrm{ml} \mathrm{min}^{-1}$ and effluent was collected and analyzed. The $\mathrm{pH}$ was adjusted using Hydrochloric acid and sodium hydroxide.

\section{Effect of temperature}

Under a temperature range of $30-70^{\circ} \mathrm{C}$, using a water bath to regulate the temperature, industrial waste was allowed to flow at a flow rate of 5 $\mathrm{ml} \mathrm{min}-1$ into the column packed with $40 \mathrm{~g}$ of rice husk and groundnut husk powder separately, effluent was then collected and analyzed using atomic absorption spectrophotometer.

\section{Effect of adsorbent combination}

$40 \mathrm{~g}$ of adsorbents (rice husk and groundnut husk powder) were combined in different percentages into the column separately, waste water was allowed to flow into the column at a flow rate of $5 \mathrm{ml} \mathrm{min}^{-1}$ and effluent was collected and analyzed using AAS.

\section{Heavy metal determination and analysis of adsorbents}

Zinc $(\mathrm{Zn})$, lead $(\mathrm{Pb})$ and manganese $(\mathrm{Mn})$ were analyzed before and after treatment. Fourier transformed infrared spectroscopy (FTIR) was carried out to identify the presence of functional groups.

\section{Adsorption experiment}

The continuous adsorption experiment was conducted by allowing fertilizer industrial waste water to flow into the column at a flow rate of $5 \mathrm{ml} / \mathrm{min}^{-1}$ and effluent was collected and analyzed using atomic absorption spectrophotometer. All experiments were carried out in duplicate and mean values determine were presented. The percentage removal of $\mathrm{Mn}(\mathrm{II}), \mathrm{Zn}(\mathrm{II})$ and $\mathrm{Pb}(\mathrm{II})$ ions were calculated from the following equation:

$$
\mathrm{R}(\%)=\frac{\left(\mathrm{C}_{\mathrm{o}}-\mathrm{C}_{\mathrm{e}}\right)}{\mathrm{C}_{\mathrm{o}}} \times 100
$$

Where $\mathrm{C}_{\mathrm{o}}$ and $\mathrm{C}_{\mathrm{e}}$ are metal ions concentrations $(\mathrm{mg} / \mathrm{L}$ ) before and after adsorption respectively. $\mathrm{M}$ is the weight of the adsorbent in grams.

\section{Statistical analysis}

The result was presented as mean \pm standard deviation.

\section{Results and Discussion}

\section{Effect of adsorbent mass on removal of metal ions}

Figure 1 shows that increased adsorbent loading increased the metal ions percentage removal. $\mathrm{Mn}^{2+}$ attained maximum removal at 30 $\mathrm{g}$ with $92.09 \%$ removal using rice husk powder as adsorbent. Increase in adsorbent dosage also increased the percentage removal of $\mathrm{Pb}^{2+}$ for both adsorbents. Lead attained maximum removal at $60 \mathrm{~g}$ with $97.35 \%$ removal using rice husk powder as adsorbent. Maximum removal of Zinc (Zn) was at $60 \mathrm{~g}$ with $96.03 \%$ removal using groundnut husk powder. The percentage removal of $\mathrm{Mn}(\mathrm{II}), \mathrm{Zn}(\mathrm{II})$ and $\mathrm{Pb}$ (II) ions in this study, increased with increasing dosage due mainly to an increase in the number of available exchangeable active sites for metal ion sorption [6].

\section{Effect of pH on removal of metal ions}

From Figure 2, it was observed that with increase in the $\mathrm{pH}$ of waste water, the percentage removal of metal ions increased and attained maximum removal for manganese at $\mathrm{pH} 6$ with $75.62 \%$ and pH 5 with $98.82 \%$ using rice husk powder and groundnut husk powder respectively. Lead had maximum removal at $\mathrm{pH} 6$ with $94.54 \%$ removal with groundnut husk powder as adsorbent. There was $100 \%$ removal of zinc at $\mathrm{pH}$ of 6 using rice husk powder as adsorbent. At low $\mathrm{pH}$, higher concentration and mobility of $\mathrm{H}^{+}$ions favour $\mathrm{H}^{+}$sorption compared to metal ions, this creates a competition between the protons and metal ions for the active sites of the biosorbent. According to Ref. [7] metal ions are more soluble in solution at lower $\mathrm{pH}$ values and this reduces their sorption. The low sorption at low $\mathrm{pH}$ was thus due to saturation of the active sites of GH and RH with hydrogen ions.

\section{Effect of temperature on removal of metal ion}

The removal of Manganese, Zinc and Lead was favored at higher temperature as shown in Figure 3. The result demonstrated that an

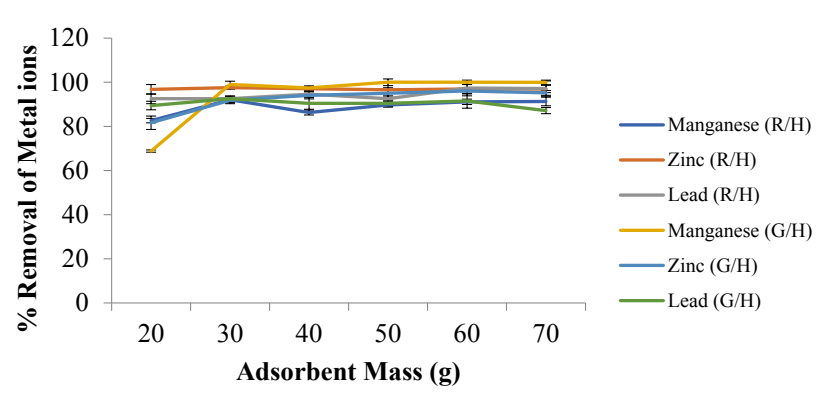

Figure 1: $\mathrm{PM}_{2.5}$ annual mean concentrations for a sample of 25 cities in the world [19].

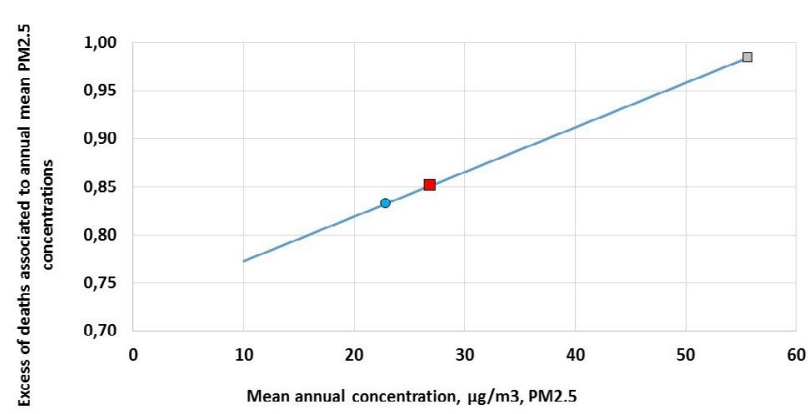

- At annual mean concentration, Aburrá Valley $\mu \mathrm{g} / \mathrm{m} 3=26,9$, daily deaths $=0,851$ - At annual mean concentration, average 25 cities $\mu \mathrm{g} / \mathrm{m} 3=22,9$, daily deaths $=0,833$ $\square$ At annual mean concentration, Beijing $\mu \mathrm{g} / \mathrm{m} 3=55,6$, daily deaths $=0,984$

Figure 2: Effect of $\mathrm{pH}$ on percentage Removal of Metal ions. R/H=Rice Husk, G/ $\mathrm{H}=$ Groundnut husk, $\mathrm{g}=\mathrm{Grams}, \%=$ Percentage. 


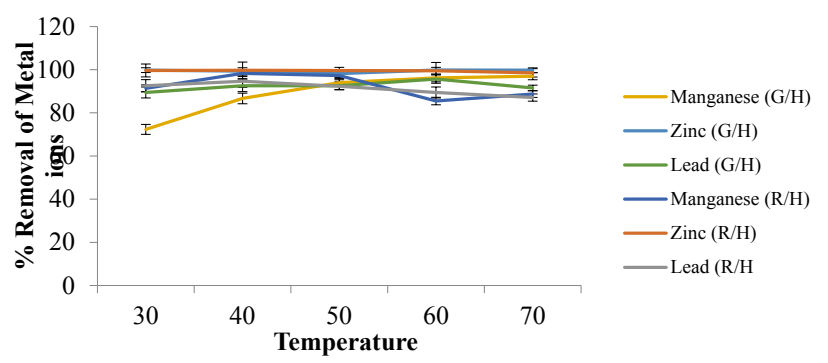

Figure 3: Effect of Temperature on Percentage Removal of metal ions. R/H=Rice Husk, $\mathrm{G} / \mathrm{H}=$ Groundnut husk, $\mathrm{g}=\mathrm{Grams}$, \%=Percentage.

increase in temperature from $30-40^{\circ} \mathrm{C}$ led to increase in the adsorption capacity from $91.38 \%$ to $98.28 \%$ for manganese with rice husk powder as adsorbent. Maximum adsorption for zinc was at $40^{\circ} \mathrm{C}$ with $99.72 \%$ removal and at $60^{\circ} \mathrm{C}$ with $99.83 \%$ removal for rice husk powder and groundnut husk powder respectively. Lead had maximum removal of $94.64 \%$ at $40^{\circ} \mathrm{C}$ and $95.64 \%$ removal at $60^{\circ} \mathrm{C}$ for rice husk powder and groundnut husk powder respectively. Further increase in temperature led to decrease in removal of metal ions as shown in Figure 3. In general increase in temperature increases the rate of a redox reaction [8]. Using a temperature range of $30-70^{\circ} \mathrm{C}$, an increasing trend of metal ions removal with increase in temperature was observed. Ref. [9] and Ref. [5] suggested that high temperature results in creation of some new sorption sites on the adsorbent surface by increasing the rate of intra particle diffusion of sorbate ions into the pores of adsorbent at higher temperature, since diffusion is often endothermic. However at a higher temperature the trend changed as the percentage removal decreased, this may be due to damage of the physical properties of the biosorbents that interferes with binding of ionic species to it.

\section{Effect of adsorbent combination on metal ion removal}

Rice husk powder (40 g) and $40 \mathrm{~g}$ groundnut husk powder were combined in various percentages as shown in Figure 4. At $60 \%$ rice husk powder combined with $40 \%$ groundnut husk powder there was maximum adsorption of $98 \%$ for manganese, while zinc had maximum adsorption of $93.90 \%$ at $60 \%$ rice husk powder and $40 \%$ groundnut husk powder combination. Lead had maximum adsorption of $89.43 \%$ at $70 \%$ rice husk powder combined with $30 \%$ groundnut husk powder. $\mathrm{GH}$ and $\mathrm{RH}$ gave a better sorption when used in isolation than when in combination. A higher percent of GH than $\mathrm{RH}$ in the combination caused a decrease in sorption capacity and percentage removal. This is possibly due to aggregation/agglomeration of sorption sites, leading to a decrease in surface area; hence sorption capacity of the biosorbents may not have been fully utilised [10]. Whereas, a high percentage removal of metal ions tends to increase as more $\mathrm{RH}$ is combined with $\mathrm{GH}$. This is possibly due to an increase in the available binding sites for metal ion [11].

\section{Fourier Transform Infra-Red Spectroscopy (FTIR) analysis}

The results of FTIR peak values and functional groups of rice husk powder and used rice husk powder are shown in Figure 5 below. IRspectrum shows the presence of Alkyl halides (R-I), Alkenes $(=\mathrm{C}-\mathrm{H})$,

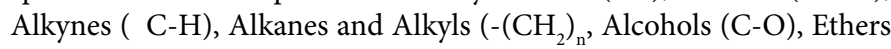
$(=\mathrm{C}-\mathrm{O}-\mathrm{C})$, Amides $(\mathrm{N}-\mathrm{H})$, Carboxylic acids $(\mathrm{O}-\mathrm{H})$, in rice husk powder while used rice husk powder shows the absence of Alkenes $(=\mathrm{C}-\mathrm{H})$ and Alkynes $(\mathrm{C} \otimes \mathrm{C})$. Figure 6 below also shows the peak values and functional groups of groundnut husk powder and used groundnut husk powder respectively. IR-spectrum shows the presence of Alkyl halides

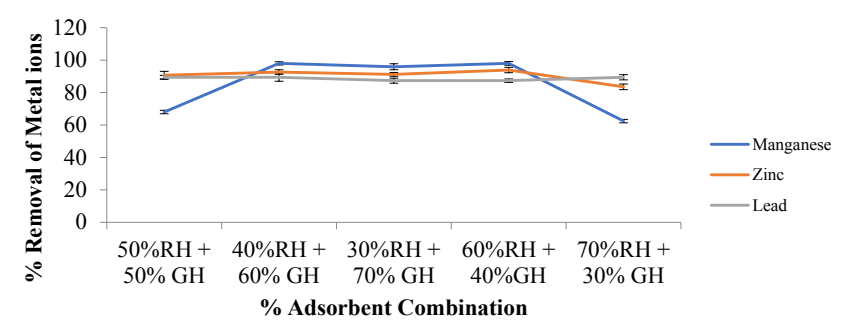

Figure 4: Effect of Adsorbent combination on Percentage Removal of metal ions. $\mathrm{R} / \mathrm{H}=$ Rice Husk, $\mathrm{G} / \mathrm{H}=$ Groundnut husk, $\mathrm{g}=$ Grams, \%=Percentage.

(R-I), Alkenes (=C-H), Aromatic compound mono substituted (C-H), Alcohols (C-O), Alkyl halides (C-F), Ethers (=C-O-C), Alkanes and Alkyls $(\mathrm{C}-\mathrm{H})$, Aromatic Compounds $(\mathrm{C}=\mathrm{C})$, Amides $(\mathrm{N}-\mathrm{H})$, Alkenes $(\mathrm{C}=\mathrm{C})$, Aldehydes $(\mathrm{C}=\mathrm{O})$, Esters $(\mathrm{C}=\mathrm{O})$, Carboxylic acids $(\mathrm{O}-\mathrm{H})$, for groundnut husk powder while the used groundnut husk powder shows the absence of Aromatic Compounds $(\mathrm{C}=\mathrm{C})$, Aldehydes $(\mathrm{C}=\mathrm{O})$, Alkenes $(\mathrm{C}=\mathrm{C})$.

\section{Adsorption isotherms}

An adsorption isotherm model gives the equilibrium relationship between the sorbate in the fluid phase (solution) and the sorbate sorbed on the sorbent at constant temperature $[4,12]$. They are very useful for obtaining the adsorption capacity so as to facilitate the evaluation of the feasibility of the adsorption process for a given application and for selection of the most appropriate sorbent at the optimum experimental conditions [12].

In this work, the Langmuir and freundlich isotherm models were employed to interpret the sorption process in order to understand the mechanism of metal ions adsorption on rice husk and groundnut husk powder. The experimental data were fitted to the aforementioned equilibrium isotherm models. Langmuir biosorption isotherm gave the best fit for sorption of metal ions using groundnut husk as indicated by their correlation coefficient which were higher than that of the freundlich isotherm while the freundlich biosorption isotherm gave the best fit using rice husk powder as indicated by their correlation coefficient which were higher than that of the Langmuir isotherm (Table 1).

The Langmuir equation [8] is given as:

$$
\mathrm{q}_{\mathrm{e}}=\frac{\mathrm{q}_{\mathrm{m}} \mathrm{k}_{\mathrm{a}} \mathrm{c}_{\mathrm{e}}}{1+\mathrm{k}_{\mathrm{a}} \mathrm{c}_{\mathrm{e}}}
$$

Where; $(\mathrm{mg} / \mathrm{g})$

$\mathrm{q}_{\mathrm{e}}=$ Amount of metal ions adsorbed per unit mass at equilibrium $\mathrm{q}_{\mathrm{m}}=$ Maximum possible amount of metal ions that can be adsorbed per unit mass of adsorbent $(\mathrm{mg} / \mathrm{g})$

$c_{e}=$ Concentration of sorbate (in solution at equilibrium (mg/l)

$\mathrm{K}_{\mathrm{a}}=$ Sorption equilibrium constant

The linearised form of equation is:

$\frac{\mathrm{c}_{\mathrm{e}}}{\mathrm{q}_{\mathrm{e}}}=\frac{1}{\mathrm{k}_{\mathrm{a}} \mathrm{q}_{\mathrm{m}}}+\frac{\mathrm{c}_{\mathrm{e}}}{\mathrm{q}_{\mathrm{f}}}$

A plot of $\frac{c_{e}}{q_{e}}$ versus $c_{e}$ gives a straight line, with a slope of $\frac{1}{q_{m}}$ and 
Citation: Nzelibe HC, Ibrahim KLC (2017) Biosorption of Heavy Metals from Fertilizer Industrial Waste Water Using Rice Husk (RH) and Groundnut Husk (GH) Powder in a Packed Bed Bioreactor. J Environ Anal Toxicol 7: 466. doi: 10.4172/2161-0525.1000466

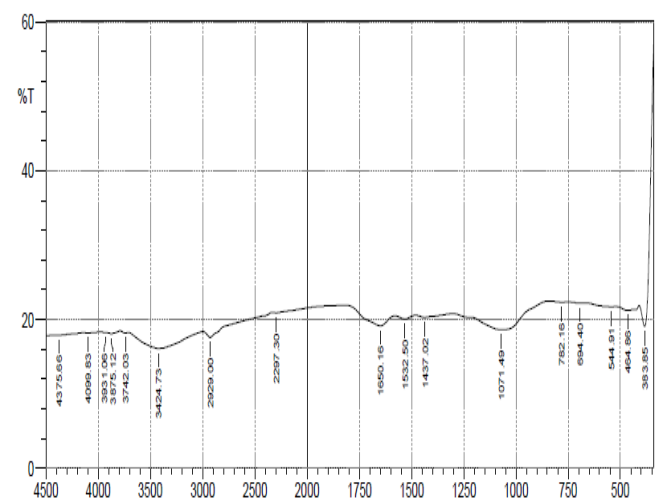

(a) Before metal ions adsorption

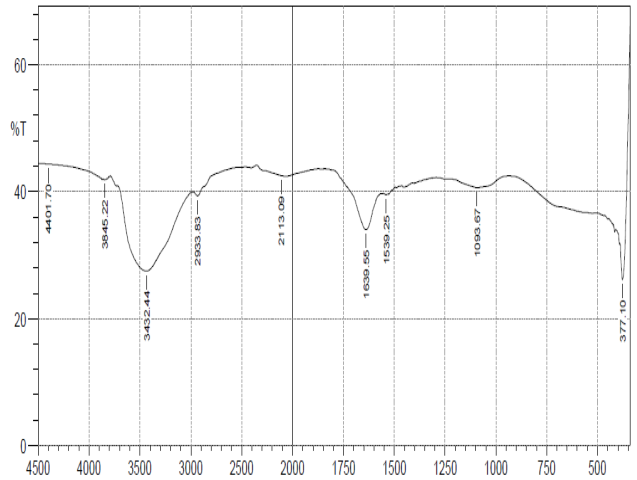

(b) After metal ions adsorption

Figure 5: FTIR spectrum of rice husk and used rice husk showing Fragment peaks.

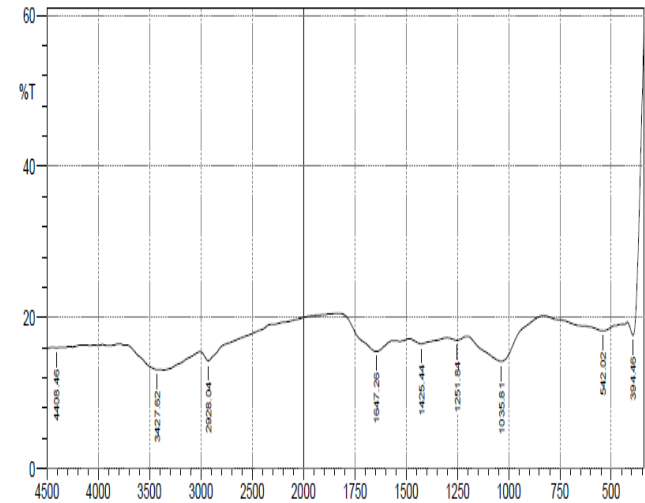

(a) Before metal ions adsorption

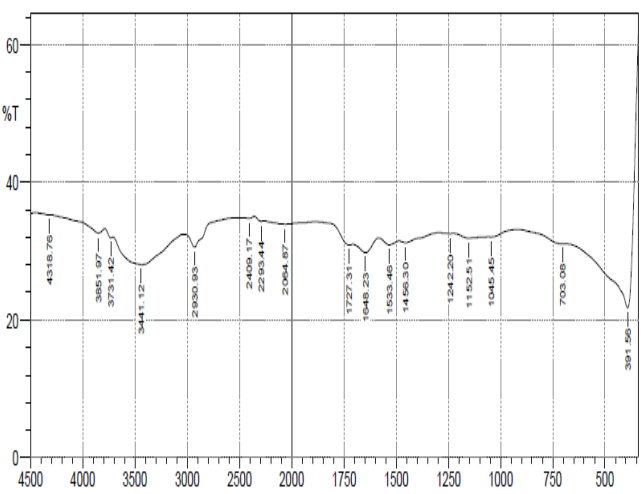

(b) After metal ions adsorption

Figure 6: FTIR spectrum of groundnut husk and used groundnut husk showing Fragment peaks.

\begin{tabular}{|c|c|c|c|c|c|c|c|}
\hline \multirow[t]{2}{*}{ Adsorbent } & \multirow[t]{2}{*}{ Metal } & \multicolumn{2}{|c|}{ Langmuir constant } & \multirow{2}{*}{$\begin{array}{c}\begin{array}{c}\text { Regression } \\
\text { Coefficient }\end{array} \\
\mathbf{R}^{2} \\
\end{array}$} & \multicolumn{2}{|c|}{ Freundlich constant } & \multirow{2}{*}{$\begin{array}{c}\begin{array}{c}\text { Regression } \\
\text { Coefficient }\end{array} \\
\mathbf{R}^{2}\end{array}$} \\
\hline & & $q_{e}$ & $\mathbf{K}_{\mathrm{L}}$ & & $K_{f}$ & $1 / n$ & \\
\hline $\mathrm{RH}$ & $\mathrm{Mn}$ & 0.000 & 0.000 & $5 \mathrm{E}-05$ & 4.709 & 0.822 & 0.332 \\
\hline $\mathrm{RH}$ & $\mathrm{Zn}$ & 3.012 & 6.916 & 0.163 & 2.338 & 0.829 & 0.441 \\
\hline $\mathrm{RH}$ & $\mathrm{Pb}$ & 5.319 & 2.848 & 0.218 & 5.714 & 0.679 & 0.556 \\
\hline $\mathrm{GH}$ & $\mathrm{Mn}$ & 16.129 & 31.000 & 0.998 & 10.423 & 0.038 & 0.014 \\
\hline $\mathrm{GH}$ & $\mathrm{Zn}$ & 19.607 & 0.485 & 0.676 & 6.194 & 0.682 & 0.842 \\
\hline $\mathrm{GH}$ & $\mathrm{Pb}$ & 0.887 & 4.838 & 0.297 & 1.039 & 0.752 & 0.056 \\
\hline
\end{tabular}

Table 1: Isotherm model parameters for the adsorption of metal ions by $\mathrm{RH}$ and $\mathrm{GH}$.

intercept $\frac{1}{\mathrm{k}_{\mathrm{a}} \mathrm{q}_{\mathrm{m}}}$

The essential characteristics of Langmuir isotherm can be expressed in terms of a dimensionless constant $K_{R}$, the separation factor or equilibrium parameter, which is defined as:

$$
\mathrm{K}_{\mathrm{R}}=\frac{1}{1+\mathrm{K}_{\mathrm{a}} \mathrm{C}_{\mathrm{o}}}
$$

Where;

$K_{R}=$ Dimension less separation factor

$K_{a}=$ Langmuir constant $(\mathrm{L} / \mathrm{mg})$
$C_{o}=$ Initial concentration of metal ions $(\mathrm{mg} / \mathrm{L})$

The shape of the isotherm is linear if $\mathrm{K}_{\mathrm{R}}=1$, it is irreversible if $\mathrm{K}_{\mathrm{R}}<0$, unfavourable if $K_{R}>1$ and favourable if $0<K_{R}<1(46,47)$.

The Freundlich isotherm is an empirical model which indicates the surface heterogeneity of the adsorbent. The equation is given as:

$\mathrm{q}_{\mathrm{e}}=\mathrm{K}_{f} \mathrm{C}_{\mathrm{e}}{ }^{1 / \mathrm{n}}$

The linear form of the equation is:

$\log \mathrm{q}_{\mathrm{e}}=\log \mathrm{k}_{f}+1 / n \log \mathrm{c}_{\mathrm{e}}$

Where; 
Citation: Nzelibe HC, Ibrahim KLC (2017) Biosorption of Heavy Metals from Fertilizer Industrial Waste Water Using Rice Husk (RH) and Groundnut Husk (GH) Powder in a Packed Bed Bioreactor. J Environ Anal Toxicol 7: 466. doi: 10.4172/2161-0525.1000466

Page 5 of 5

$q_{e}=$ the amount of sorbate adsorbed at equilibrium $(\mathrm{mg} / \mathrm{g})$

$\mathrm{k}_{f}(\mathrm{~L} / \mathrm{g})$ and $n=$ Freundlich constants which indicate the adsorption capacity of the adsorbent and adsorption intensity, respectively $\left.\mathrm{dm}^{3}\right)$

$\mathrm{C}_{e}=$ The equilibrium concentration of sorbate in the solution (mg/

A plot of $\log q_{e}$ versus $\log c_{e}$ gives a straight line of slope $1 / n$ and intercept $\log \mathrm{k}_{f}$ from which $n$ and $\mathrm{k}_{f}$ can be evaluated. If $1 / n<1$, then the adsorption is favorable and the adsorption capacity increases with the occurrence of new adsorption sites. But if $1 / n>1$, the adsorption bond becomes weak and unfavorable adsorption takes place, leading to a decrease in adsorption capacity.

\section{Conclusion}

The potential of modified rice husk and groundnut husk for the removal of $\mathrm{Mn}(\mathrm{II}), \mathrm{Zn}(\mathrm{II})$ and $\mathrm{Pb}(\mathrm{II})$ ions from aqueous solutions was dependent on biosorption process such as $\mathrm{pH}$, temperature and biosorbent dose. The equilibrium data have been analyzed using Langmuir and freundlich isotherms. The characteristics parameters for each isotherm and related correlation coefficients $\mathrm{R}^{2}$ were determined. The Langmuir biosorption isotherm were demonstrated to provide the best correlation for the biosorption of $\mathrm{Mn}(\mathrm{II}), \mathrm{Zn}$ (II) and $\mathrm{Pb}$ (II) ions onto GH powder while the freundlich biosorption isotherm provided the best correlation coefficient for the biosorption of $\mathrm{Mn}$ (II), $\mathrm{Zn}$ (II) and $\mathrm{Pb}(\mathrm{II})$ ions unto $\mathrm{RH}$ powder. It can be concluded that since the RH and GH powder is an easily, locally available, low cost adsorbent and has a considerable high biosorption capacity, it may be treated as an alternative adsorbent for the treatment of waste water containing $\mathrm{Mn}(\mathrm{II}), \mathrm{Zn}(\mathrm{II})$ and $\mathrm{Pb}(\mathrm{II})$ ions.

\section{Acknowledgements}

I would like to show my gratitude to my colleagues for sharing their pearls of wisdom with me during the course of this research. I am also immensely grateful to my lecturers for comments that greatly improved the manuscript.

\section{References}

1. Abia AA, Igwe JC (2005) Sorption kinetics and intraparticulate diffusivities of $\mathrm{Cd}, \mathrm{Pb}$ and $\mathrm{Zn}$ ions on maize cob. African Journal of Biotechnology 4: 509.

2. El-Sharkawy EA (2001) Adsorption of textile dyes on to activated carbons synthesized from solid waste: Decolourizing power in relation to surface properties. Adsorption Science \& Technology 19: 795-811.

3. Volesky B, Bohumil B (1990) Biosorption and biosorbents, in biosorption of heavy metals. CRC Press, Boca Raton, Florida, pp: 3-5.

4. Sathishkumar M, Jung SH, Song SH, Yun SI (2009) A novel method in utilization of bokbunja seed wastes from wineries in liquid-phase sequestration of reactive blue 4. International Journal of Environmental Research 3: 1-2.

5. Guo TO, Onukwuli DO, Olaitan SA, Atuanya CU, Akagu CC, et al. (2002) Effect of filler weight fraction on the mechanical properties of bambara groundnut (okpa) husk polyethylene composite. International Journal of Current Research 5: 1714-1717.

6. Guler UA, Sarioglu M (2013) Single and binary biosorption of $\mathrm{Cu}$ (II), Ni (II) and methylene blue by raw and pretreated Spirogyra sp.: Equilibrium and kinetic modeling. Journal of Environmental Chemical Engineering 1: 369-377.

7. Onundi YB, Mamun AA, Al Khatib MF, Ahmed YM (2010) Adsorption of copper, nickel and lead ions from synthetic semiconductor industrial wastewater by palm shell activated carbon. International Journal of Environmental Science \& Technology 7: 751-758.

8. Ashraf MA, Wajid A, Mahmood K, Maah MJ, Yusoff I (2011) Low cost biosorbent banana peel (Musa sapientum) for the removal of heavy metals. Scientific Research and Essays 6: 4055-4064.

9. Das B, Mondal NK (2000) Calcareous soil as a new adsorbent to remove lead from aqueous solution: equilibrium, kinetic and thermodynamic study. University Journal of Environmental Resource and Technology 1: 515-530.

10. Li Y, Xia B, Zhao Q, Liu F, Zhang $P$, et al. (2011) Removal of copper ions from aqueous solution by calcium alginate immobilized kaolin. Journal of Environmental Sciences 23: 404-411.

11. Sakthi V, Andal NM, Rengaraj S, Sillanpää M (2010) Removal of Pb (II) ions from aqueous solutions using Bombax ceiba saw dust activated carbon. Desalination and Water Treatment 16: 262-270.

12. Dinçer AR, Güneş $Y$, Karakaya N, Güneş E (2007) Comparison of activated carbon and bottom ash for removal of reactive dye from aqueous solution. Bioresource Technology 98: 834-839. 